\author{
Tomasz WÓJTOWICZ ${ }^{1}$ \\ Dariusz KRÓL ${ }^{2}$
}

\title{
CHINESE CONCEPT OF UNRESTRICTED WARFARE - CHARACTERISTICS AND CONTEMPORARY USE
}

\begin{abstract}
The political, economic and military rivalry between the United States and the People's Republic of China is one of the most important aspects of the changing global distribution of powers. It prompts investigations into the Chinese war-making practice and the Chinese line of thought about warfare, thus facilitating the understanding of decisions made by Beijing authorities. The objective of this article is to outline the Chinese concept of unrestricted warfare - its origins, characteristics and contemporary use. The principal research issue resulting from the assumed objective was to respond to the following question: What is unrestricted warfare, and how it is currently used by the Chinese People's Liberation Army? The following research methods were employed to solve the research queries: a monographic method, a document examination method, literature analysis and criticism, and methods of analysis and synthesis. Considering their preliminary investigations, the authors formulated the following research hypothesis: the concept of unrestricted warfare is one of the most important Chinese concepts describing its war-making practice and rivalry with the United States. Although it was developed over 20 years ago, it still forms a valid selection of warmaking methods and forms. Non-military forms of warfare, including financial warfare, trade warfare, resources warfare, economic warfare or regulation warfare are particularly important and frequently used by the People's Republic of China.
\end{abstract}

Keywords: The People's Republic of China, unrestricted warfare, financial warfare, trade warfare, terrorism, the United States.

\section{INTRODUCTION}

The concept of unrestricted warfare developed in 1999 was one of the most common Chinese concepts of war-making. 20 years later, its content still appears valid, when we consider its use in the official governmental military documents and measures taken by China in relation to the United States and Taiwan. It is said that Jiang Zemin, President of the People's Republic of China, and Chi Haotiana, Minister of Defence, were among the readers of Unrestricted Warfare. In 2003, the Central Military Commission used that basis

\footnotetext{
${ }^{1}$ Tomasz Wójtowicz, Ph.D., Institute of Security Sciences, Pedagogical University of Cracow, ul. R. Ingardena 4, 30-060 Kraków; e-mail: tomasz.wojtowicz2@up.krakow.pl. ORCID: 00000001-6468-8973.

2 Dariusz Król, M.Sc., Department of Humanities and Social Sciences, Ignacy Łukasiewicz Rzeszow University of Technology, Rzeszów, al. Powstańców Warszawy 12, 35-959 Rzeszów; e-mail: d.krol1@prz.edu.pl (corresponding author). ORCID: 0000-0003-4682-5238.
} 
to publish the Three Warfares doctrine which focused in particular on psychological operations, media manipulation, and the use of national and international law for political purposes. Together with Unrestricted Warfare which is the underlying source of knowledge on the Chinese concept, the authors also referred to other concise publications, articles and reports devoted to China's international activities and its rivalry with the United States. These included studies by Air War College, official doctrines of the U.S. Armed Forces and articles published in "Journal of Economic and Behavioral Studies", "Forbes", "The Diplomat" and Polish papers: "Kultura i Polityka" [Culture and Politics] and "Przegląd Nauk o Obronności" [A review of defence sciences]. The article contains introductory and concluding sections, as well as two substantive sections. The first of these provides characteristics of the concept of unrestricted warfare. It presents the profiles of Chinese officers - founders of the theory, the evolution of the international security environment at the turn of the 20th and 21 st centuries, the forms of unrestricted warfare, its rules and principles. The second part focuses on the contemporary use of unrestricted warfare by the People's Republic of China.

\section{CHARACTERISTICS OF THE CONCEPT OF UNRESTRICTED WARFARE}

The concept of unrestricted warfare was presented in 1999 in Unrestricted Warfare, a book written by two military officers of the Chinese People's Liberation Army, Qiao Liang and Wang Xiangsui. Today it is still one of the most frequently cited publications dealing with the Chinese line of thought about warfare and war-making practices. The first author, Qiao Liang, was born in 1955 in the Shanxi Province, to a military family. He served in the Air Forces of the Chinese People's Liberation Army, where he attained the rank of major general (corresponding to the rank of brigade general in the Polish army) before retiring. Along with completing military service, he was also Head of the Council for National Security Policy Studies and a member of the Chinese Writers' Association. He has authored and co-authored a number of publications devoted to Chinese air forces, reforms in the Chinese army and international military relations. The second author, Wang Xiangsui, was born in 1954 in Guangzhou, also to a military family. He joined the Chinese People's Liberation Army in 1970 as a political office, subsequently assuming the positions of political instructor, group political commissar and division deputy political commissar. He then served in the Air Forces, eventually attaining the rank of colonel. Having been sent to the reserve, he became Professor at the Beihang University (Liang, Xiangsui, 1999).

The publication by Qiao Liang and Wang Xiangsui does not merely contain a description of the concept of unrestricted warfare but it also highlights the significance of new technologies in facilitating revolutions in military affairs as well as describes the Chinese and American war-making practices. It further outlines the American weaknesses and causes of failure in previous unsuccessful U.S. military operations, as well as presents the changing environment of international security. In doing so, the authors identified several threats expected to dominate the line of thought about national security in a few years' perspective - the so-called postmodern terrorism (the 11/09 attacks) and financial crises resulting from speculations. The authors proved to have a comprehensive knowledge of the American military literature, including field manuals and strategic documents outlining the transformation directions of the U.S. armed forces. Special attention was paid to analysing the Gulf War which, according to the authors, was a landmark political event and a major military conflict. Iraq's operations connected with the military invasion of 
Kuwait were unequivocally assessed in a negative way. Contrary to Iran where hostages were taken and an unsuccessful intervention of the U.S. special forces was carried out, Baghdad's actions led to establishing a great international coalition composed of 30 countries, and 2 million soldiers, led by the United States (Liang, Xiangsui, 1999). In the warfare 500 new military technologies, which were developed in the 1980s, were used. Fights took place in all possible domains at that time, including land, sea, air, space and information domains, also affecting non-military spheres - diplomacy, international law and economy (with sanctions imposed on Iraq). The publication in question also described the changing environment of national security. The Chinese officers drew attention to the gradual loss of the monopoly on aggression which nation states had acquired after the end of the Thirty Years' War in 1648. At the same time, international organisations, huge corporations and non-state entities, such as terrorist organisations, started to grow in importance. The latter, by employing asymmetrical warfare methods, attempted irrational competition against such powers as the United States, Japan and Russia, eventually achieving some successes reported by media. Among these were successful terrorist attacks, i.e. the Tokyo subway attack of 12 March 1995 and the U.S. embassy bombings in Kenya and Tanzania on 7 August 1998. The boundary between soldiers and non-combatants became blurred, with hackers, terrorists and financial speculators becoming symbols of modern warriors. George Soros is a person whose name appears several times in the publication. His activities are said to have contributed to the emergence of financial crises - first in Southeast Asia where an attack was launched on the Hong Kong dollar and Hong Kong stocks, especially the "red-chip stocks" controlled by the People's Republic of China, and then in Russia where his statements regarding financial collapse of that country led to investors' massively selling off Russian securities (Liang, Xiangsui, 1999).

Taking into consideration the historical significance of an information-based revolution in military affairs and the changing environment of national security, Qiao Liang and Wang Xiangsui formulated theses highlighting the changing image of contemporary warfare. In the authors' opinion, warfare has become unrestricted. It is a conflict in which military force no longer constitutes the only means to compel the enemy to submit to one's will, but it rather involves using all means, including military and non-military, and lethal and nonlethal means (Liang, Xiangsui, 1999). It is worth noting that the notion of unrestricted warfare has not been expressly defined in the western line of military thought. In American governmental documents and scientific studies, such terms as irregular warfare and hybrid warfare are used, which exhibit some similarities (Luke, 2012). In Joint Publication 1, Doctrine for the Armed Forces of the United States, irregular warfare was defined as a violent struggle among state and non-state actors, and a conflict in which the weaker party tries to question the dominance of its stronger opponent (Join Publication, 2010). In turn, Frank Hoffman, a former American military officer and academic teacher dealing with the issues of contemporary warfare, presented hybrid warfare as a form of conflict involving a mix of conventional weapons, irregular tactics, terrorism, and even criminal behaviour to obtain certain political objectives. Despite some similarities in these definitions, the American war-making practice is far different from the Chinese one. It concentrates on using the armed force to defeat the opponent in a symmetrical conflict while avoiding the mobilisation of the entire society or the engagement of all resources and state administration (Luke, 2012).

The authors of the concept of unrestricted warfare also listed numerous types of such warfare: atomic warfare, conventional warfare, bio-chemical warfare, space warfare, 
electronic warfare, guerrilla warfare, terrorist warfare, diplomatic warfare, network warfare, intelligence warfare, psychological warfare, smuggling warfare, drug warfare, tactical warfare, technological warfare, fabrication warfare, financial warfare, trade warfare, resources warfare, economic warfare, sanction warfare, regulation warfare, ecological warfare, ideological warfare, media warfare, cultural warfare, and lawfare. The abovementioned types of warfare were grouped into the following three categories (forms): military, trans-military and non-military, as shown in the table below (Luke, 2012).

Table 1. Forms of unrestricted warfare

\begin{tabular}{|l|l|l|}
\hline Military & Trans-military & Non-military \\
\hline Atomic warfare & Diplomatic warfare & Financial warfare \\
\hline Conventional warfare & Network warfare & Trade warfare \\
\hline Bio-chemical warfare & Intelligence warfare & Resources warfare \\
\hline Space warfare & Psychological warfare & Economic warfare \\
\hline Electronic warfare & Smuggling warfare & Sanction warfare \\
\hline Guerrilla warfare & Drug warfare & Regulation warfare \\
\hline Terrorist warfare & Tactical warfare & Ecological warfare \\
\hline & Technological warfare & Ideological warfare \\
\hline & Fabrication warfare & Media warfare \\
\hline & & Cultural warfare \\
\hline
\end{tabular}

Source: author's own compilation based on (Luke, 2012)

Most of these types of warfare have been described in much detail in western literature and western war-making concepts. However, it is worth paying attention to some of the forms whose significance tends to be neglected, or which do not constitute major research areas for western intellectuals and military strategists. These are: resources warfare, regulation warfare, fabrication warfare, technological warfare, and tactical warfare. Resources warfare is defined as gaining control over rare and natural resources with the aim of taking control of access to said resources and interfering with markets. The concentration process involving numerous industrial plants in China, also pharmaceutical plants, is given as an example of resources warfare. This issue is presented in China Rx: Exposing the Risk of America's Dependence on China for Medicine Hardcover. According to the authors, most drugs of everyday use are no longer produced in the United States but in China, this fact being concealed by pharmaceutical companies. In the event of an open military conflict in the Western Pacific, it may happen that Americans will no longer have access to the most common painkillers which they normally use. In addition, China produces worse-quality drugs which may cause poisonings (Gibson, 2018). Regulation warfare was presented as joining an international or supranational organisation with the purpose of challenging its policies or influencing the law-making process so as to meet national interests. It also implies exploiting international law to exert influence on other states. Fabrication warfare means developing a counterfeit appearance of the reality or presenting the opponent on the international arena in a manner that contradicts the truth. Technological warfare was described as attempting to gain competitive edge in access to major technologies which could be used both in peace and war times. Finally, tactical warfare implies using conventional and non-conventional resources to win battles (Luke, 2012). 
The concept of unrestricted warfare includes not only a list of possible forms of warmaking and competition, but also some principles according to which operations against opponents should be planned. The following terms are used among others: the golden point, the side-principal rule or deviation toward the side element, and the ideology of going beyond limits. The "golden point" principle implies that any warfare has its key moment (turning point), following which the scales of victory tip to either side. For instance, during the Napoleonic wars the golden point was Napoleon's entering Moscow (1812); during World War II this was the Battle of Stalingrad (1942), and during the Gulf War - the point at which the losses of military equipment sustained by the Iraqi Republican Guards exceeded 30 percent. As regards deviation toward the side element, the idea is to properly select targets and to identify the opponent's weak points or areas where it does not expect an attack to be launched. The sneak attack on Pearl Harbour was an example of this principle being put into operation (Luke, 2012). Finally, the ideology of going beyond limits refers to Niccolo Machiavelli who admitted the use of unethical means to achieve an objective, which clearly represented a breakthrough against the romantic chivalry prevailing in the medieval period. When transposed to contemporary warfare, this ideology implies conducting activities outside the narrowly understood military area, also spanning across diplomacy, economy and finance. This principle was deliberately or non-deliberately used by the United States during the Gulf War, whereby the potential of conventional armed forces was combined with both wide diplomatic offensive and imposition of sanctions on Iraq. In contrast, Saddam Hussein displayed huge ignorance in reaching exclusively for such tools that were based on armed force when seeking to put the territory of a foreign country under Iraqi control (Luke, 2012).

One of the key elements of the concept of unrestricted warfare is the section outlining eight principles enabling the conduction of "beyond-limits combined war". These are: omnidirectionality, synchrony, limited objectives, unlimited measures, asymmetry, minimal consumption, multidimensional coordination, and control of the entire process. Omnidirectionality refers to conducting operations in many domains - in land, maritime, air, space and information, as well as economic, political and cultural domains. As stressed by the authors, a modern battlefield can still be a densely forested land in which guerrilla fights take place, but the virtual world of media and the active role of journalists can as well serve this function (Chew, 2018). While discussing synchrony, which concerns the ability to conduct actions in different spaces within the same period of time, Qiao Liang and Wang Xiangsui appreciatively mentioned the "Desert Storm" operation and the American capacities of synchronising the military campaign. The Americans, by employing the newest situational awareness and $\mathrm{C} 4$ (Command, Control, Communication \& Computers) systems, were capable of exchanging information on 4,000 targets and passing it to 1,200 aircraft within a minute. This also reflected the ideology of going beyond limits which consisted in the implementation of total depth while performing airborne and missile attacks (Luke, 2012). The principle of limited objectives emphasises the need to determine objectives both cautiously and reasonably, by giving full consideration to the feasibility of accomplishing them. As claimed by the authors,

When setting objectives, one must overcome the mentality of craving great successes, and instead consciously pursue limited objectives and eliminate objectives which are beyond one's abilities, even though they may be proper. (...). 
Setting objectives which exceed allowable limits of the measures available will only lead to disastrous consequences (Luke, 2012).

The principle of unlimited measures is closely connected with limited objectives, as it implies the use of any available measures, both military and non-military. Sherman's advance in the American war between the north and south, by the end of 1864, was an example of how effective this principle could be. While destroying the resources and logistic infrastructure of the Confederation army engaged in the northern state, Virginia, it also contributed to breaking the morale of the civilian population as a result of severe losses sustained during that "advance" (Chew, 2018). The asymmetry of power is another principle, describing how the weaker party (in this case China) should approach the stronger opponent (the United States) in the warfare context. The suggested approach is different from the one that was utilised in the conflict between the USSR and the USA in the Cold War period, and in particular in the 1980s when the Kremlin decided to join the arms race in order to attain the level of technological advancement matching that of the American army and naval forces. China's approach should now be completely different. First, it should be based on developing an innovative economy attracting talented scientists and engineers. Second, it should involve the transformation of armed forces to make them capable of fighting against the USA by exploiting its weak points (Chew, 2018).

There have been many examples of confrontation in the world's history in which the weaker parties, by employing asymmetrical warfare methods, were able to win battles and force their enemies to withdraw or change their plans. These include the First Chechen War, the activity of the Irish Republican Army in the United Kingdom, the American Battle of Mogadishu in 1993, or the terrorist attacks launched in western countries by Islamic groups. The key to success in asymmetrical warfare lies in the weaker party's avoiding any direct confrontation with its enemy using conventional armed forces. The forms of unrestricted warfare to be used in such circumstances include guerrilla warfare, terrorist warfare and virtual warfare (Luke, 2012). The principle of minimal consumption stresses the need to use the least amount of resources to accomplish a set objective. The Battle of Verdun in 1916, which is called by war historians a meat grinder, was an example of an ill-matched approach to the use of resources by Germany and France. Between 21 February and 18 December 1916 , both parties lost as many as 686,000 soldiers. This was in contrast to the German Blitzkrieg during World War II which allowed great successes to be accomplished with losses cut to the minimum - crossing the Maginot Line in France (Chew, 2018). The principle of multidimensional coordination highlights the need for coordination and cooperation during operations conducted in all domains and competition spheres, whether military or non-military. In contemporary conflicts, this depends on the level of warfare. According to the authors, there are four such levels, i.e. the grand war fought at the highest political command level (war policy), the war at the strategic level, the war at the campaign level (operational art), and the war at the battle level (military tactics). The control of the entire process is based on adjusting the strategy to the changing situation, with the ChinaVietnam War of 1979 constituting an example. Due to growing losses sustained by the PLA, Beijing decided to withdraw its troops from Vietnam, announcing that all of its assumed objectives had been accomplished. The Chinese intervention which consisted in quickly attacking several cities located in the northern regions of the country lasted 27 days. The American intervention which, similar to the Chinese one, also ended in failure, lasted 19 years (Chew, 2018). 


\section{CHINA'S CONTEMPORARY USE OF THE CONCEPT OF UNRESTRICTED WARFARE}

As early as in mid-1990s, strategists of the Chinese People's Liberation Army coined the term "information warfare" which emphasised the significance of attaining a dominant position in the information area, both as regards the command systems and battlefield control, and asymmetrical psychological operations aimed to undermine the morale of the enemy's soldiers and to overcome resistance in certain societies.

As part of the planned operations, China adopted a range of methods including standard striking mechanisms aimed to destroy main bases, field commands, and information control and command centres, and conducting far-reaching electronic fights, including the use of electronic means of jamming and electromagnetic weapons to attack the enemy's information and intelligence collection systems (such as radar and communication systems).

Far-reaching disinformation measures, including the use of operations such as tactical feints (simulated attacks) to shield or deceive the enemy's intelligence collection systems, were also envisaged together with the use of all means to maintain secrecy and keep the enemy from collecting intelligence on Chinese operations, and the use of TV, radio, and leaflets to undermine the enemy's military morale (Baocun, Fei, 1995).

At present, the unrestricted warfare doctrine is reflected in an array of concepts implemented by the Chinese People's Liberation Army. An example of these is the Three Warfares concept developed in 2003, aimed at undermining the opponent's resistance and accomplishing certain national objectives - at the same making a minimum input in the potential real fight. The said concept is, to a large extent, based on the following three fundamental types of operations related to information warfare, among which the following are mentioned:

1. Strategic psychological operations - which involve simulating the use of armed forces in the form of para-military organisations, the application of other capabilities (diplomatic or economic), or reference to cultural aspects, with the intention of intimidating the adversary and encouraging acquiescence to the outcomes desired by the People's Republic of China;

2. Media manipulations - based on delivering tailored materials to public audiences through established news services, informal internet sites, and other social media, with the intention to create an unreal image of the situation, distinctively favourable for the People's Republic of China, and thus to justify China's actions pursued on the international arena.

3. Exploitation of national and international legal systems - which involves leveraging the existing legal regimes in some countries or coalitions to block or constrain the adversary's behaviour, and thus to maximize advantage in situations related to China's interests (Livermore, 2018).

The status attained by the Chinese People's Liberation Army, which can be seen as extension of power exercised by the Chinese Communist Party, acquires a special meaning in this context. It facilitates cutting the potential external interference into the Middle Kingdom's internal affairs and foreign policy to the minimum. In the Chinese system, it is the army that integrates all areas of the meticulously expanded nation's power. The contemporary Chinese military strategy strongly highlights the essence of information dominance within modern non-kinetic conflicts. So, the Three Warfares concept makes it 
possible to effectively secure Chinese national interests while avoiding the need to engage armed forces in any potential conflicts of a conventional character.

Given the above, China has portrayed its participation in the rivalry in the South China Sea basin as a national interest, intrinsically connected with both its territorial integrity and security. The so-called Nine Dash Line, covering a vast part of the islands situated in the said region (mainly the Paracel Islands and the Spratly Islands) is the leading motive of the dispute. Apparently insignificant (given especially their rather small area), these islands practically allow for the South China Sea to be considered territorial waters of the People's Republic of China, excluded from the jurisdiction of international maritime law. Notably, the disputed region constitutes one of the busiest trade routes as well as features numerous gas and oil deposits which materially increase its overall attractiveness.

In 2013, the People's Republic of China commenced selective ground reclamation and construction of new (artificial) islands in order for these to be adapted to serve as coastal fortifications. Measures taken to this end caused protests of other countries situated in the vicinity of the islands, including Vietnam, Philippines, Brunei, Malaysia and Taiwan, all definitely rejecting the Chinese claims. In this context, China opted for a "showcase" use of the Three Warfares doctrine to justify its interest without causing a conventional armed conflict (Livermore, 2018).

The construction of coastal fortifications in the disputed region is intended to exert a psychological effect on the remaining parties to the dispute. Among the coastal installations constructed by the Chinese People's Liberation Army, the following are worth mentioning: advanced air defence systems, launchers for anti-ship ballistic missiles (including HQ-9 anti-aircraft batteries - equivalents of the Russian $S$-300 systems with operational range of up to $200 \mathrm{~km}$ (Mencel, 2017), as well as $D F-21 D$ and $D F-26$ (Stashwick, 2010) anti-ship ballistic missiles), observation drones, and air force bases equipped with modern combat aircraft (Minh Tri, 2017; DoD, 2017).

With a view to strengthening China's own capabilities of exercising supervision over the disputed area, without the need to resort to warships, elements of Chinese coast guards were deployed in the said region and adapted to conduct operations, thus forcing the opponents to leave the waters claimed by the Middle Kingdom. New structures such as huge coast guard's patrol ships Haixun 09, suited to conducting operations aimed at protecting the country's territorial waters, e.g. by harassing and ramming other countries' vessels, can serve this purpose well (Axe, 2021).

Attention should be paid to the significant development of the Chinese naval forces, including the supply of numerous ships of new types, among which the successively introduced vessels classified as missile destroyers of type $052 \mathrm{C}$, type $052 \mathrm{D}$ (around 28 ships with displacement of 7000 and 7200 tonnes, respectively) and type 055 (8 ships planned with displacement of around 13000 tonnes, based on which they can be practically classified as rocket cruisers, outperformed only by the American Zumwalt class destroyers with displacement of around 16000 tonnes) are worth mentioning (Office of Navel Intelligence, 2020). The warships are equipped, inter alia, with $Y J-18$ anti-ship ballistic missiles with estimated range of $220-540 \mathrm{~km}, H H Q-9$ long-range interceptors placed in 64 (type $052 \mathrm{D}$ ) or 112 (type 055) vertical launch systems (DoD, 2017; Military-Today, 2021).

As part of expanding its naval forces, the People's Republic of China has launched an aircraft carrier development programme - so far the following two ships have been assigned such a status: Liaoning (classified as type 001, a Kuzniecow type aircraft cruiser purchased from the Russian Federation with displacement of 67000 tonnes, which can carry $J-15$ 
Shenyang type combat aircraft - licensed copies of the Russian Su-33) and Shandong (classified as type 002, constituting an enlarged version of Liaoning with displacement of around 70000 tonnes, also intended to carry $J-15$ type aircraft) (ChinaPower, 2021). Based on intelligence reports and satellite observations, more ships are currently under construction. These will, however, represent a new type of warships (preliminarily classified as type 003) with estimated displacement of around 85000 tonnes and a modified flight deck structure. It is reported that two type 003 ships have already entered the construction stage (Stashwick, 2021). All the above structures are powered by steam turbines with diesel generators, while the planned (type 004) warship will use nuclear power (Mizokami, 2018) - this fact testifying to a significant acceleration of the development rate of the Chinese navy, and its power projection capacities.

In order to strengthen the psychological impact of diplomatic activities implemented in the South China Sea basin, media services were extensively used, which involved in particular disseminating facts about the historic affiliation of the reference area. This included media contents spread via news services and other media agencies. At the same time, the People's Republic of China effectively prevented other regional players from reacting to its provocations related to military capabilities, the use of propaganda and various legal ambiguities. All those activities have bought Beijing some time to further strengthen its standing in the region and to continue the militarisation of local islands. This is likely to eventually act as a deterrent for other countries competing for that region, at the same time sending a message that their capabilities to oppose China's territorial claims are gradually diminishing (Livermore, 2018).

The People's Republic of China has been effectively building its image in media as a country threatened by external forces, while pretending to avoid direct military confrontation (using the offensive approach to accomplish its objectives only to a minimum extent). This acts as a proof that all measures taken by the Chinese authorities are intended to ensure the country's security.

Psychologically, the "Three Warfares" concept which entails media content manipulations with exploiting legal complexities, provides adequate means for implementing the strategic objectives assumed by the Middle Kingdom with an opportunity to control conflict escalations in disputed regions. Excluding the South China Sea from the jurisdiction of international maritime law can ultimately result in weakening the international standing of the United States and their allies, mainly by losing control over major trade routes in that region. The intensifying tension is reflected in the growing number of incidents involving Chinese coast guard's patrol ships and vessels belonging to the United States Navy (Livermore, 2018).

Beijing's diplomatic protests of 2016 (widely publicised in media) can be seen as an example - the American USS William P. Lawrence (type Alreight Burke) missile destroyer, while conducting a freedom of navigation operation, entered the Spratly Islands region, which triggered a rather abrupt reaction. China immediately deployed its fighter jets and sent three ships to that region, forcing the American vessel to instantly leave the archipelago. The People's Republic of China also took care of the proper media message to make it clear that the construction of defence installations in the region was necessary and well-grounded (LaGrone, 2016).

In September 2018, another incident took place involving the American warship approaching the Spratly Islands - the USS Decatur (type Alreight Burke) missile destroyer was almost rammed by the Chinese Lanzhou (type 052C) missile destroyer causing the 
American vessel to immediately withdraw. As in the previous case, the Chinese party considered its conduct fully justified, claiming that its destroyer merely acted in response to the American ship violating Chinese territorial waters (Werner, 2018).

In July 2020, the Chinese embassy strongly disapproved of the U.S. rejection of its territorial claims regarding the South China Sea, sending a message that the United States sought to disturb the Chinese cooperation with other countries situated in the disputed region. The Chinese authorities further emphasised that the United States, as a country not directly affected by the conflict, should abstain from interfering in the disputes to which they are not a party. In response, U.S. Defence Secretary Mike Pompeo clearly stated that the United States intended to maintain stability in the region and uphold the freedom of navigation, with an ultimate attempt to secure uninterrupted flow of goods (Pamuk, 2020).

The above examples prove that the conflict in the region concerned has been escalating. Beijing - pursuing its policy involving militarisation of the South China Sea - wants to put pressure on the international community demanding that the sea be considered exclusively Chinese. By building artificial islands, constructing military bases equipped with shelters, anti-missile and anti-ship systems, as well as airfields, it creates a kind of an "anti-access bubble" in the region to exert pressure on the countries situated within the South China Sea basin. This also poses a real problem for the United States which cannot venture to lose an area so crucial for global trade.

Economic warfare, trade warfare and resources warfare are other examples of the contemporary use of the unrestricted warfare concept. China is gradually advancing is political impacts in Latin America, Africa and the Middle East by investing in such sectors as construction, logistics, manufacture, communications and retail trade. China's foreign assistance and loans granted by its financial institutions appear more attractive to many countries as they do not combine public aid with issues of human rights or democratic power. The Beijing Consensus does not raise a range of expectations for poor countries regarding economic freedom, the need to privatise state-owned industrial plants or openness to direct foreign investments. It has thus become an alternative for the Washington Consensus, enabling developing countries to decide about their own political system and development directions (Strojek, 2011). In 2000-2014, major recipients of Chinese loans in Africa included Angola, Ethiopia, Kenya, the Democratic Republic of Congo, the Republic of Congo, Niger, Ghana and Cameroon (Mlambo, Mlambo, Mubecua, 2018). In addition, the United States accuse China of currency manipulation, as well as of inadmissible trade subsidies and intellectual property theft. In 2009, during a hearing before the United States congressional committee, Secretary of the U.S. Department of the Treasury Timothy Geithner testified that China had been deliberately manipulating its own currency in order to keep it at a low level in relation to dollar and other currencies. This was meant to foster high exports and keep the prices of goods produced in the Middle Kingdom as low as possible in relation to the prices dictated by the market. Beijing was also said to subsidise some other exported products such as stationery products, textiles, steel and plastic products, which resulted in eliminating a significant number of jobs in the United States. The above-described practices have directly contributed to the dynamic growth of the Chinese economy in the past 10 years, at a rate of $10 \%$ of GDP, and significantly reduced the development gap between China and the United States (Luke, 2012). 


\section{CONCLUDING REMARKS}

The concept of unrestricted warfare should be treated as a selection of views consistent with the historic Chinese war-making practice - one that emphasises the element of surprise, misleading, intermediate actions and forcing the enemy to surrender without recourse to military power. The examples presented in the second part of the article prove how intensively the trans-military and non-military warfare methods are currently used by the People's Republic of China. Along with financial warfare, trade warfare, resources warfare, economic warfare and regulation warfare, Beijing also resorts to psychological, diplomatic and network warfare. Assuming that a potential conflict with the United States and their allies in West Pacific would progress according to the "escalation ladder", a conclusion can be drawn that the methods applied by the People's Republic of China at the rivalry stage are indeed effective. They enable reducing the American impact without the need to declare war, along with building China's economic and political power. However, it is very hard to say whether the asymmetrical warfare methods would be the paragon of success if an open American-Chinese war began. The U.S. military forces are prepared for conventional fights with any type of enemy, retaining their dominance both at sea and in air. They still have the most advanced military technologies and a wider range of atomic weapons. This work does not exhaust the topic related to the concept of unrestricted warfare. Along with characterising it, it provides a selection of examples of how that concept is currently used by China. It may thus serve as the starting point to other research and attempts at both investigating how Beijing authorities, by using diplomatic means, weaken the U.S. alliances with countries situated in South-Eastern Asia, and responding to the following questions: How are media and social networking sites used to disseminate the "Chinese point of view"? Does China conduct activities aimed at political destabilisation of the countries they consider as their opponents? The authors of this article believe that the concept of unrestricted warfare should be analysed with extreme diligence in Poland as it provides an array of suggestions on how to compete against and make war with a country with more powerful military and technological potential.

\section{REFERENCES}

Axe, D. (2021). Huge New Chinese Ships Are Made For Ramming [access: 3.03.2021]. Access on the internet: https://www.forbes.com/sites/davidaxe/2021/01/15/huge-new-chineseships-are-made-for-ramming/?sh $=663866 \mathrm{bc} 1 \mathrm{c} 19$

Baocun, W., Fei, L. (1995). Information Warfare [access: 8.03.2021]. Access on the internet: fas.org/irp/world/china/docs/iw_wang.htm

Chew, J. (2018). How China Applies its "Principles of Unrestricted Warfare" in the 21st Century. Galisteo Consulting Group, Inc. Technical Report.

ChinaPower (2021). What Do We Know (so far) about China's Second Aircraft Carrier [access: 1.03.2021]. Access on the internet: chinapower.csis.org/china-aircraft-carrier-type-001a/

Department of Defense (2017). Military and Security Developments Involving the People's Republic of China, Annual Report to Congress Office of the Secretary of Defense.

Gibson, R., Singh, J. P. (2018). China Rx: Exposing the Risk of America's Dependence on China for Medicine Hardcover Prometheus.

Joint Chief of Staff (2013). Join Publication 1 Doctrine for the Armed Forces of the United States [access: 10.07.2021]. Access on the internet: https://www.jcs.mil/Portals/36/ Documents/Doctrine/pubs/jp1_ch1.pdf 
Mencel, M. (2017). Morze Poludniowochińskie w polityce bezpieczeństwa ChRL i USA w XXI wieku [The South China Sea in the security policy of the People's Republic of China and the USA in the 21st century]. "Przeglad Nauk o Obronnosici" [A review of defence sciences], No. 2.

Minh Tri, N. (2017). China's A2/AD Challenge in the South China Sea: Security the Air From the Ground [access: 10.02.2021]. Access on the internet: thediplomat.com/2017/05/chinasa2ad-challenge-in-the-south-china-sea-securing-the-air-from-the-ground/

Military-Today (2021). Type 055 class Guided Missile Cruiser [access: 2.03.2021]. Access on the internet: www.military-today.com/navy/type_055_class.htm

Mizokami, K. (2018). Inside China's Plan to Build the Second-Biggest Aircraft Carrier Fleet in the World [access: 2.03.2021]. Access on the internet: foxtrotalpha.jalopnik.com/insidechina-s-plan-to-build-the-second-biggest-aircraf-1828730033

Mlambo, D.N., Mlambo, V. M., Mubecua, M. A.(2018). The Rise of Chinese Investments in Africa: For Whose Benefit?. "Journal of Economics and Behavioral Studies", Vol. 10, No. 4.

LaGrone, S. (2016). U.S. Destroyer Passes Near Chinese Artificial Island in South China Sea Freedom of Navigation Operation [access: 3.03.2021]. Access on the internet: news.usni.org/2016/05/10/u-s-destroyer-passes-near-chinese-artificial-island-in-southchina-sea-freedom-of-navigation-operation

Liang, Q., Xiangsui, W. (1999). Unrestricted Warfare. Beijing: PLA Literature and Arts Publishing House.

Livermore, D. (2018). China's "Three Warfares" In Theory and Practice in the South China Sea [access: 01.03.2021]. Access on the internet: georgetownsecuritystudiesreview.org/ 2018/03/25/chinas-three-warfares-in-theory-and-practice-in-the-south-china-sea/

Luke, B. K. (2012). Reconginizing and Adapting to Unrestricted Warfare Practices by China. A Research Report Submitted to the Faculty. Air War College.

Office of Navel Intelligence (2020). China People's Liberation Army Navy (Plan), Coast and Government Maritime Forces [access: 1.03.2021]. Access on the internet: https://tiny.pl/ rnm1

Pamuk, H., Mohammed, A., Lun Tian, Y. (2020). U.S. rejects China's claims in South China Sea, adding to tensions [access: 5.03.2021]. Access on the internet: www.reuters.com/ article/us-usa-china-southchinasea-idUSKCN24E2OU

Stashwick, S. (2021). Third Chinese Aircraft Carrier Nears Completion Amid Shipyard Expansion [access: 2.03.2021]. Access on the internet: thediplomat.com/2021/01/thirdchinese-aircraft-carrier-nears-completion-amid-shipyard-expansion/

Strojek, J. (2011). W kierunku konsensusu pekińskiego [Towards Beijing consensus?]. „, Kultura i Polityka" [Culture and Politics], No. 9.

Werner, B. (2018). Destroyer USS Decatur Has Close Encounter With Chinese Warship [access: 1.03.2021]. Access on the internet: news.usni.org/2018/10/01/37006

DOI: $10.7862 /$ rz.2021.hss.39

The text was submitted to the editorial office: July 2021.

The text was accepted for publication: December 2021. 